\title{
The Politics of LGBT Policy Adoption: Shibuya Ward's Same- Sex Partnership Certificates in the Japanese Context

\author{
Yasuo Takao
}

\begin{abstract}
This article will examine the determinants of LGBT (lesbian, gay, bisexual, and transgender) policy adoption in Shibuya, one of the twenty-three city wards of Tokyo, by taking an actor-specific approach to the first case of officially recognized same-sex partnership in Japan. How did the sexual minority issue become the subject of official agendas? How did actors both inside and outside the municipal government seize agenda-setting opportunities for government action? The results indicate that key policy makers' entrepreneurship played a primary role in the official recognition of same-sex partnership by linking policy solutions with agenda-setting opportunities. This analysis demonstrates that the adoption of municipal LGBT policy does not necessarily reflect the redistribution of non-material resources, such as citizen values, but rather resembles the patterns of welfare politics.
\end{abstract}

Keywords: LGBT, same-sex partnership, sexual minority, morality politics, Shibuya, Japan

DOI: http:/ /dx.doi.org/10.5509/20179017

\section{Introduction}

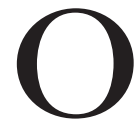

n March 31, 2015, Shibuya, one of the twenty-three city wards of Tokyo, passed the Ordinance for Promoting Respect of Gender Equality and Diversity in the Ward. Article 10 introduces the issuance of "same-sex partnership certificates" for the first time in Japan. Why did Shibuya adopt the same-sex partnership policy when it did? There are three

YASUO TAKao is a senior lecturer of political science in the Department of Social Sciences and Security Studies, Curtin University, Australia. His current research interest resides in the area of societal transnationalism at the grassroots level in Japan. His latest publication is Japan's Environmental Politics and Governance: From Trading Nation to Eco-Nation (Routledge 2016). Email: y.takao@curtin. edu.au

* The author would like to gratefully acknowledge the assistance of Ken Hasebe, Shüji Minato, and Susan Takao. 
possible causes for new policy adoption in a broad sense: increased need, ${ }^{1}$ available financial resources, and changes to basic value structures. ${ }^{2}$ The first explanation for Shibuya's new policy is as a direct response to increased need, as people living in Japanese metropolitan areas are exposed to more diverse lifestyles. Yet the demographic shifts and the emergence of community diversity and urbanism are too gradual to account for Shibuya's stand-alone initiative to pass the ordinance. The second explanation can be found in most case studies about policy making that involve a large commitment of financial resources. In morally charged issue areas, such as same-sex partnership, the availability of financial resources cannot fully account for new policy adoption, since the redistribution of values, not economic selfinterests, are at stake. ${ }^{3}$ The third explanation is a reflection of value conflicts that may challenge the conventional interpretation of urban politics. Policy outputs may reflect changes in public opinion but deep-rooted value structures would not change significantly in a short period of time. In essence, new policy adoption is not an automatic product of structural factors, but reflects decisions made individually and collectively by human agents. This study will look beneath the aggregate relationships to more qualitative evidence of localized motives and behaviour for Shibuya's initiative to issue "same-sex partnership certificates."

This requires clear empirical research of human agents, who were able to individually and collectively interpret the political opportunity structures of the morally charged issue to meet locally specific needs. The literature on "morality politics" suggests that moral issues, such as same-sex marriage, constitute a distinctive type of policy formation through a redistribution of societal and religious values, ${ }^{4}$ while others challenge the morality politics framework by pointing out that the material interests of political actors are still the primary determinants of policy making. ${ }^{5}$ From this material interestsbased perspective, as interest groups, such as sexual minorities, lobby policy elites to protect their interests, interest group resources, policy elite attitudes, and existing public policies are the primary determinants of policy making. However, Donald Haider-Markel and Kenneth Meier argue that, when groups

1 Paul A. Sabatier and Hank C. Jenkins-Smith, "The advocacy coalition framework: an assessment," in Theories of the Policy Process, ed. Paul A. Sabatier (Boulder, CO: Westview Press, 1999), 149.

$2 \quad$ Sabatier and Jenkins-Smith identify public opinion shifts as "external shocks," which are one prerequisite for changes to deep-rooted policy core beliefs. See Sabatier and Jenkins-Smith, "The advocacy coalition framework," 122. For these three causes as cross-national determinants for policy growth, see Harold L. Wilensky, The Welfare State and Equality (Berkeley: University of California Press, 1975).

Elaine B. Sharp, "Introduction," in Culture Wars and Local Politics, ed. Elaine B. Sharp (Lawrence: University of Kansas Press, 1999), 8.

James D. Hunter, Culture Wars: The Struggle to Define America (New York: Basic, 1991); Kenneth J. Meier, The Politics of Sin: Drugs, Alcohol, and Public Policy (Armonk, NY: M. E. Sharpe, 1994); Raymond Tatalovich and Byron W. Daynes, eds., Moral Controversies in American Politics (Armonk: Sharpe, 1998).

Ira Sharkansky, Spending in the American States (Chicago: Rand McNally, 1968); Paul Peterson, City Limits (Chicago: University of Chicago Press, 1981). 
opposed to minority rights expand "the scope of the conflict" to electoral competition, political conflicts become highly salient and the political pattern begins to resemble moral politics. ${ }^{6}$

The maintenance of social consensus is well known as a pervasive feature of Japanese society. Japan presents a difficult case study, where we would not expect minority groups to obtain official recognition in an easy way. To explore this country-specific case, a number of scholars emphasize the key role played by local authorities in coming up with a responsible solution to meet the need of minority protection. ${ }^{7}$ In the areas of minority issues that may address the fundamental values of society, however, there is a need to explain dissimilar cases in policy making, i.e., why morally charged issues become or do not become salient and politicized and how the patterns of morality politics, if any, can account for variation in policy making. It would appear that political opportunity structures $(\mathrm{POSs})^{8}$ are the most useful approaches to cross-national comparisons of politics. The POS is used to explain how different structures determine the variations of agent behaviour, that is, how POSs allow or constrain actors to position themselves on morally charged issues and how these issues subsequently become a driving force in the formation of political coalitions and in electoral competition. However, although ascribing a significant part of policy adoption to morally charged issues, the POS tends to explain the basic features of politics, rather than illuminating the dynamic process in which opportunity structure translates into policy outcomes. In this respect, rather than focusing attention on the structural nature of state institutions, one may capture a dynamic ongoing process of policy making that stretches over a considerable time period and involves various interests and participants. To meet this analytical need, the role of actor-specific "policy entrepreneurs" is most suited for the analysis of such policy processes on a local scale. ${ }^{9}$ In urban areas, mayoral

${ }_{6}$ Donald P. Haider-Markel and Kenneth J. Meier, "The politics of gay and lesbian rights: expanding the scope of the conflict," Journal of Politics 58, no. 2 (1996): 332-349. The scope of a political conflict is defined by multiple factors: involvement of actors, attention from the media and the public, issue characteristics and framing, political institutions, and policy processes. See Frank R. Baumgartner and Bryan D. Jones, Agendas and Instability in American Politics (Chicago: University of Chicago Press, 1993).

Peter J. Herzog, Japan's Pseudo-Democracy (New York: New York University Press, 1993), 89-91; Katherine Tegtmeyer Pak, "Foreigners are local citizens, too: local governments respond to international migration in Japan," in Japan and Global Migration: Foreign Workers and the Advent of a Multicultural Society, eds. Mike Douglass and Glenda S. Roberts (London: Routledge, 2000), 244-274; Seung-Mi Han, "From the communitarian ideal to the public sphere: the making of foreigners' assemblies in Kawasaki city and Kanagawa prefecture," Social Science Japan Journal 7, no. 1 (2004): 41-60; Apichai W. Shipper, Fighting for Foreigners: Immigration and its Impact on Japanese Democracy (Ithaca: Cornell University Press, 2008), 128-155.

8 Herbert Kitschelt, "Political opportunities structures and political protest: anti-nuclear movements in four democracies," British Journal of Political Science 16 (1986): 57-85; Hanspeter Kriesi, et al., New Social Movements in Western Europe: A Comparative Analysis (Minneapolis, MN: University of Minnesota Press, 1995).

Alexander L. George, "Political leadership and social change in American cities," Daedalus 96, no. 4 (1968): 1197; Jeffrey L. Pressman, "Preconditions of mayoral leadership," American Political 
entrepreneurship is a key ingredient affecting a city's ability to introduce innovations. In this article, policy entrepreneur refers to an individual who possesses the skills and drive to make, within the constraints of limited initial resources, others behave in ways that he/she desires. The concept of policy entrepreneurship is also integrated within the agenda-setting analyses of new policy adoption. This agenda-setting theory focuses on the role played by policy entrepreneurs who exploit agenda-setting opportunities for policy solutions. ${ }^{10}$ Another important aspect of agenda setting for new policy adoption is issue definition (shaped by actors, issue attention, framing, issue characteristics) with which institutional control is combined to make possible a sudden shift in policy development. ${ }^{11}$

Finally, from the viewpoint of international relations scholars, minority rights are closely intertwined with the workings of international norms. International antidiscrimination norms inevitably work their influence through the efforts of domestic entrepreneurs. ${ }^{12}$ Indeed, Amy Gurowitz illustrates how these entrepreneurs, such as local authorities, use international norms in domestic contexts to push for policy changes. ${ }^{13}$ The legitimacy of international norms can provide a structural opportunity for agenda setting at the local level.

Therefore, state structures do not determine the specific content and course of decision making yet agenda setting takes place in the framework of state and societal institutions for policy change. In this article, an integrated approach encompassing both institutional structures and agenda setting will thus be considered to work in tandem.

Science Review 66, no. 2 (1972): 511-524; Mark Schneider, Paul Teske, and Michael Mintrom, Public Entrepreneurs: Agents for Change in American Government (Princeton, NJ: Princeton University Press, 1995); Michael Mintrom and Sandra Vergari, "Policy networks and innovation diffusion: the case of state education reforms," Journal of Politics 60 (1998): 126-148; Michael Mintrom, Policy Entrepreneurs and School Choice (Washington, DC: Georgetown University Press, 2000).

10 John W. Kingdon, Agenda, Alternatives and Public Policies (Boston: Little, Brown and Company, 1984), chapters 7 and 8. Kingdon's understanding of "policy windows" is equivalent to social movement theorists' concept of political opportunity structures, although this concept is applied to activists who must exploit the opportunities. See David S. Meyer, "Protest and political opportunities," Annual Review of Sociology 30 (2004): 128.

11 Baumgartner and Jones, Agendas and Instability in American Politics, 16. Matt Grossmann found it surprising that resource advantages do not necessarily lead to policy success in US issue-specific networks. See Matt Grossmann, "Interest group influence on U.S. policy change: an assessment based on policy history," Interest Groups $\mathcal{F}^{2}$ Advocacy 1, no. 2 (2012): 171-192. In the EU context, a number of scholars have used the concept of policy entrepreneurs to illustrate policy changes, with special reference to policy framing and policy networks for promoting policy change. See, for example, Daniel Béland, "Ideas, institutions, and policy change," Journal of European Public Policy 16 (2009): 701-718; Marcel Braun, "The evolution of emissions trading in the European Union- the role of policy networks, knowledge and policy entrepreneurs," Accounting, Organizations and Society 34 (2009): 469-487.

12 Martha Finnemore and Kathryn Sikkink, "International norm dynamics and political change," International Organization 52, no. 4 (1988): 887-917.

13 Amy Gurowitz, "Mobilizing international norms: domestic actors, immigrants, and the Japanese state," World Politics 51 (1999): 413-445. 


\section{Issue-specific Opportunity Structure}

To explore Japan's politics of LGBT policy making, we need to distinguish between "general openness in the polity" and "openness to particular constituencies, that is, issue-specific opportunities." ${ }^{14}$ In general, Japan's coalition behaviour is framed by a low degree of "openness" in the political opportunity structure, that is, high territorial centralization and one-party dominance in a unitary state. The structural nature of Japan's state institutions is less likely to provide the political opportunity structures that induce the formation of coalition building to create a dynamic process of high competition between coalitions of actors. The dominant governing coalition tends to control a given policy subsystem and produce coalition stability over a long period of time..$^{15}$ One of the most important opportunity structures, peculiar to morality politics, which channel societal demands into the political system, concerns whether major political parties are closely tied to religious groups. The answer to this question produces "two worlds of morality politics": the religious world and the secular world. ${ }^{16}$ Morality issues are most likely to be politicized by religion-affiliated major parties in party systems (e.g., those in Austria, Belgium, and Germany). In Japan, there are no major religious parties (except for a ruling coalition junior partner, Kōmeitō) and the majority of major conservative parties are unwilling to adopt a set of indivisible social values over other sets of competing values, thus emphasizing the rhetorical principles of conservative values. The secularized party system is not driven by a set of predetermined values, but rather shaped by a matter of non-straightforward conflict definition. Major conservative parties' concerns with social values provide a political opportunity for keeping a low degree of openness in the policy subsystem of morality issues. As LGBT issues have not as yet become heavily politicized, the narrow scope of conflict is less likely to increase the political salience and will advantage the dominant conservative coalition. The politics of the low salient issue do not generally result in two competing coalitions formed around policy core beliefs and/or partisanship. The party in power tends to avoid political actors other than minority LGBT groups and thus seeks to maintain the dominant governing coalition. To this end, conservative political elites will not change their conservative policy beliefs yet may incrementally revise prior public policies (i.e., specific policy instruments, not policy core beliefs) to acknowledge

14 David S. Meyer and Debra C. Minkoff, "Conceptualizing political opportunity," Social Forces 82, no. 4 (2004): 15-48.

15 Paul A. Sabatier and Hank C. Jenkins-Smith, "An advocacy coalition model of policy change and the role of policy oriented learning therein,” Policy Sciences 21, no. 2-3 (1988): 141f, 142.

16 Isabelle Engeli, Christoffer Green-Pedersen, and Lars Thorup Larsen, Morality Politics in Western Europe: Parties, Agendas and Policy Choices (New York: Palgrave Macmillan, 2012). 
LGBT rights to some degree. ${ }^{17}$ This narrow scope does not reveal a distinct type of politics over morally charged issues but rather is consistent with interest group politics that sees political actors as being instrumentally rational.

However, the issue-specific opportunity structure of morality politics suggests that once morality policies evoke a widespread response from the public, conservative politicians could be dragged into electoral competition. As the scope of the conflict expands, the influence of interest groups decreases in policy making. ${ }^{18}$ Strong party competition is likely to increase the level of openness to citizens' voices. As LGBT issues challenge deep-rooted religious beliefs, elected officials often need to reduce the policy to a normative stance on right or wrong. LGBT policy will be increasingly influenced by the distribution of citizen values, party competition, and partisanship, and thus shape the patterns of morality politics. ${ }^{19}$ In Japan, the citizen values that are reflected in public opinion are not divisive enough to send a warning signal to national policy makers. ${ }^{20}$ On 10 March 2015, Ganbare Nippon (Stand Firm, Japan!, a right-wing political group $)^{21}$ organized a protest in front of Shibuya Ward office against the proposed same-sex partnership, while a counter-protest was staged in central Shibuya by LGBT support groups. Nonetheless, nationally organized interest groups such as Nippon Kaigi (Japan Conference, another right-wing lobby group) ${ }^{22}$ opposed to LGBT rights have yet to expand the scope of the LGBT-related conflict in interest group politics at the national

17 See Paul A. Sabatier and Christopher M. Weible, "The advocacy coalition framework: innovations and clarification," in Theories of the Policy Process, ed. Paul A. Sabatier (Boulder, CO: Westview Press, 2007), 194-196.

18 Elmer Eric Schattschneider, The Semi-Sovereign People (New York: Holt, Reinhart, and Winston, $1960)$.

19 Haider-Markel and Meier, "The politics of gay and lesbian rights."

20 Since 1981, the World Values Survey has asked respondents in various countries to give their levels of acceptance toward homosexuality on a scale from 1 ("never justifiable") to 10 ("always justifiable"). The average score in the United States (5.4 points in 2010) puts it about in the middle of scores for member countries of the OECD, where acceptance levels continue to increase. Yet, in 2010, while 22.2 percent of respondents in the US gave their attitude toward homosexuality 10 points, 24.9 percent of the population still gave it 1 point. The American public is evenly divided over the morality of homosexuality. The average score in Japan (5.1 points in 2010) likewise places it in the middle ranks, though the number of respondents who gave it 10 points has risen rapidly, from 2.0 percent in 1981 to 14.4 percent in 2010. Yet the relatively high 21.5 percent of Japanese people surveyed who gave it 1 point in 2010 would seem to indicate that conservative values on this issue in Japan remain very influential. See World Values Survey, WVS Data-Archive, 2016, http://www. worldvaluessurvey.org/WVSPublicationsPresentations.jsp, accessed 3 May 2016.

${ }^{21}$ In February 2010, the inauguration of this political group was led by filmmaker Satoru Mizushima and former Self-Defense Force officer Toshio Tamogami, with 2,600 nationalists in attendance. See Wall Street Journal, “Japan's nationalist movement strengthens,” 14 August 2012.

${ }_{22}$ Nippon Kaigi (Japan Conference) is the largest right-wing advocacy network in Japan, which united right-wing movements in the mid-1990s under the banner of rebuilding "traditional values of Japan." This rising nationalism is known as "Tea Party politics in Japan." The network has 242 local chapters and around 38,000 fee-paying members, including approximately 230 National Diet members who are mostly conservatives from the LDP. One of the targets for national unity is the elimination of gender-free education, but they have not yet directly addressed the issue of same-sex marriage. See Tamotsu Sugano, Nippon Kaigi no kenkyū [Inquiry on Nippon Kaigi] (Tokyo: Fusōsha, 2016). 
level. A large proportion of LGBT policy measures in Japan are not driven by a strong top-down national undertaking. The absence of national guidance and the national government's inaction present an opening for proactive LGBT policy at the local level but it does not open the opportunity structures wide enough to progressively expand a pro-LGBT coalition to the national level. Morality issues also present a challenge to the traditional analytical framework of urban politics, which is fought around the allocation of economic resources or material interests. ${ }^{23}$ Indivisible moral values are now at stake in many urban issues such as same-sex marriages. The priority of local authorities has been to provide for the consumption requirements of various groups in the local population. ${ }^{24}$ I claim that local governments are at the forefront of coping with community diversity and urbanism and, because of the national government's reluctance to manage the new redistribution of social values, they are in a position to ensure the enhancement of the community's diverse lifestyles. In this context, a local to national flow of policy transfer is politically feasible when the redistribution of social values comes to reflect the influence of electoral and party competition at the national level. Otherwise, inter-local flows are likely to dominate the processes of policy diffusion in the area of morally charged issues.

\section{Sexual Minority Status in the Japanese Legal System}

Japan's democratic constitution, which went into effect in 1947, states: "Marriage shall be based only on the mutual consent of both sexes and it shall be maintained through mutual cooperation with the equal rights of husband and wife as a basis" (Article 24). The intent of the provision was to abolish the old system of a patriarchal household and respect the freedom of consenting adults to marry but not to emphasize that marriage must exist solely between a man and a woman. Some scholars argue further that, since Article 13, which states, "All of the people shall be respected as individuals," is a general provision for the guarantee of fundamental human rights, the special family-related provision of Article 24 should be interpreted in tandem with Article 13. In their view, Article 24 is applicable to same-sex couples. ${ }^{25}$ Although Article 13 declares that individuals' rights "shall be the supreme consideration in legislation and in other governmental affairs," no statutory

23 Elaine Sharp, "Introduction," in Culture Wars and Local Politics, ed. Elaine Sharp (Lawrence: University of Kansas Press, 1999), 1-20.

24 Peter Saunders, "Rethinking local politics," in Local Socialism? Labour Councils and New Alternatives, eds. Martin Boddy and Colin Fudge (London: Macmillan, 1984), 22-48.

${ }_{25}$ See for example, Shūhei Ninomiya, Kazuku-hō [Family law], 2nd ed. (Tokyo: Shinseisha, 2005), 38-39; Takahiro Sasaki, "Nihon ni okeru seiteki mainorite sabetsu to rippō seisaku - (2)" [Legislative policy and discrimination against sexual minorities in Japan - part 2], Kokusai kōkyō seisaku kenkyū 18, no. 1 (2013): 229-230; Yoshikazu Yamashita, "Shibuya-ku jōrei no igi: pātonāshippu kara dōseikon e" [Significance of Shibya Ward's ordinance: from partnership to same-sex marriage], Jurisuto 1485 (2015): 69-70. 
regulations in Japan have been legislated for same-sex marriages. In short, the Japanese legal system has continually ignored sexual minority issues, although not explicitly criminalizing homosexual behaviour.

Under the rule of law, the use of litigation as a conflict-solving mechanism is common among minority groups in Japan, as the problems of minority groups do not directly affect the majority of the population. The judicial system provides minority groups with an institutionalized opportunity to have a considerable impact on the climate of public opinion. In the 1990s, exploiting the judicial opportunity, Japanese gay and lesbian activists, such as the Society of Gay and Lesbian Activists, also tried to move sexual minority issues into this specific institutional arena. Perhaps the most publicized case was the one in which the Tokyo Metropolitan Government refused to allow a LGBT group called OCCUR to use government-owned facilities in 1990. In 1997 the Tokyo High Court ordered the Tokyo Metropolitan Government to pay damages to the group, arguing that the defendant should have proper knowledge and sensitivity about homosexuality ${ }^{26}$ Still, recourse to lawsuits is unlikely to result in a transcendence of the confines of the existing legal system. Such actions are less likely to lead to new policy or a new policy belief; at most, they might legally force the government to change the scope of existing policy in an incremental way.

In response to Shibuya's local initiatives, the mass media often reported it as a stepping stone to the legalization of same-sex marriages at the national level. ${ }^{27}$ In the Japanese context, however, the political implication of recognizing same-sex couples as having an equal right to marry under the existing legal system reveals a serious impediment toward promoting the protection of sexual minorities' rights. There are Japan-specific legal conditions that both parties must meet in order to lawfully marry each other. Probably the most difficult hurdle to overcome for the legalization of samesex marriage is the current system of koseki (Japan's family registry system), which serves to record and certify an individual's identity, not by the unit of the individual, but by the unit of $k o$ (the administrative household).$^{28}$ Despite the legal and social reforms in postwar Japan, the family registry system continues to function as a remnant of the prewar system that espouses the ideology of patriarchy. ${ }^{29}$ This ideology is based on the norm of heterosexuality and so views the personal relationships of same-sex couples as illegitimate, leading to the constitutional interpretation of Article 24 that marriage is

26 "Gays win lodging discrimination suit against Tokyo," Japan Times, 16 September 1997.

27 See for example, "Shasetsu" [Editorial], Tokyo shinbun, 27 March 2015; "Dōseikon kuni ga mitomete" [State needs to recognize same-sex marriages], Mainichi shinbun, 16 December 2015.

28 Vera Mackie, "Birth registration and the right to have rights: the changing family and unchanging Koseki," in Japan's Household Registration System and Citizenship: Koseki, Identification and Documentation, eds. Karl Jakob Krogness and David Chapman (London: Routledge, 2014), $203-221$.

29 See, for example, Lindale White, "Challenging the heteronormative family in the koseki: surname, legitimacy and unmarried mothers," in Japan's Household Registration System and Citizenship, 239-256. 
exclusive to opposite-sex couples. When a couple marries, they must file a notification of their marriage to create a new koseki for the household. Marriage is not legally binding until the municipal office grants the new family registry. Each family registry must have only one surname name and one head of the household. The person who is listed at the top of the family registry is called the hittōsha (first-listed person) and all other family members are recorded under his or her surname. If same-sex marriage is legalized and incorporated into the existing legal marriage system, the official records of personal status and the family relations could become an ideological tool of state control over LGBT rights. LGBT support networks in Japan, such as Rainbow Talk 2006, are facing a situation of much greater complexity between the legal protection of sexual minority rights and a potential risk of state control over the freedom of same-sex marriages. ${ }^{30}$ Therefore, the legal system of the family registry continues to create the high degree of "closedness" to particular constituencies, i.e., sexual minorities, in the political opportunity structure.

\section{Japanese National Politics of LGBT Issues}

In Japan, while gender identity disorder (GID) was a taboo subject, in 1997 the Japanese Society of Psychiatry and Neurology's Special Committee announced a guideline that acknowledged sex reassignment surgery as proper medical conduct. In May 2001 Masae Torai and five other transsexual plaintiffs filed civil lawsuits to have their registered genders changed, while petitioning the Ministry of Health, Labor and Welfare to change their registered sex on insurance and social security documents. Family courts failed to endorse such changes to the family registry, except for the case of "factual error" that had been made in the initial entry. ${ }^{31}$ In the same month, a working group for GID-related legislation was created among the ruling parties and its draft proposal for GID law was approved within the governing Liberal Democratic Party (LDP) a month later. In January 2003, the advocacy NAO group (No Assignment of Opposite Gender), which was led by Torai, began to lobby legislators, such as LDP Diet member Chieko Noono (a nurse scientist), who had chaired the working group. ${ }^{32}$ In April 2003 assembly councillor Aya Kamikawa, who became the first elected transsexual politician in Japan for the Setagaya Ward Assembly, joined the group's lobbying activities. ${ }^{33}$ In July 2003 the National Diet passed the Act on Special Cases in

30 Tetsuya Shida, "Dōseikekkon hihan" [A critical analysis of same-sex marriage], in Chōhatsu suru sekushariti [Provocative sexuality], eds. Tetsuya Shida and Osamu Seki (Tokyo: Shinsensha, 2009), 133-167; Yuri Horie, "Dōseikan no kon'in ni kansuru hikanteki kōsatsu" [A critical analysis of samesex marriage], Shakai shisutemu kenkyū 21(2010): 37-57.

31 “Court vetoes gender change on Family Register," Mainichi shinbun, 29 August 2002.

32 Masae Torai, Otoko no koseki o kudasai [Give us the male koseki] (Tokyo: Mainichi shinbun, 2003), 144-145, 150-152.

Torai, Otoko no koseki o kudasai, 151-152. 
Handling Gender for People with Gender Identity Disorder, which permits an applicant with GID to legally change their gender in the family registry. The family registry, which is embedded in the remnants of patriarchy in gender relations, would function as a device to force the legal gender change to follow the norm of heterosexuality. ${ }^{34}$ It would appear that the legal conditions attached to gender change show the governing LDP's reluctance to address sexual minority issues and its adherence to a heterosexual norm. The law requires that the applicant must be unmarried and have no children. As discussed in the working group, these conditions were intended to avoid the resultant same-sex marriages and same-sex parents when married individuals with children change their sex. ${ }^{35}$ The conditions reveal that minority policies are more likely to be adopted when the protection of minorities does not directly conflict with majority interests. Another case in point was the 1997 Ainu Cultural Promotion Law that would promote the right of indigenous people to maintain their own cultural traditions, but avoided any acknowledgement of Ainu calls for land rights. ${ }^{36}$

The LDP thus expresses little support for sexual minority rights and seeks to maintain the norm of heterosexuality. In relation to the literature, the political salience of the morality issue is not considered high enough to be a primary campaign issue at national elections. The narrower scope of the conflict to electoral politics advantages the LDP and lags behind in providing opportunity structures to sexual minority support groups. Indeed, in recent surveys, while Japanese politicians began to use the term mainoriti (minority) in the early 2000s, ${ }^{37}$ the LDP continues to uphold the status quo and be less sympathetic towards sexual minority issues. The surveys, which were conducted by Rainbow Pride Ehime during the campaigns for Lower House elections in 2012 and 2014, asked the national headquarters of the political parties about their views on sexual minority issues. ${ }^{38}$ In both surveys, among six parties responding to the survey questions, it was only the LDP that opposed both legalized same-sex marriage and civil partnership. With regard to sexual minority rights, the LDP replied, "Measures are necessary for people with gender identity disorder but not for homosexuals." Responding to

34 Mariko Tsutsui, "Keshisarareta genda no shiten: seidōitsu seishōgai ho no mondaiten" [Viewpoint of erased gender: the problems of GID law], Inpakushon 137 (2003): 174-181; Yuri Horie, "Seiteki shōsūsha no shintai to kokka no shōnin" [Sexual minority's body and the state's recognition], Kaihō shakaigaku kenkyū 21 (2007): 43-61.

35 Horie, "Seiteki shōsūsha no shintai to kokka no shōnin," 49.

36 Kaori Takeda, "Mainoriti o meguru seiji katei bunseki no tame no rironteki kōsatsu" [Theoretical consideration for the analysis of political processes over minorities], GEMC Journal 3 (2010): 153 .

37 Akiko Iwama, "Nihon ni okeru mainoriti" [Minorities in Japan], in Mainoriti towa nanika: gainen to seisaku no hikaku shakaigaku [What is a minority? Comparative sociology of concept and policy], eds. Akiko Iwama and Kōshō Rysh (Kyoto: Minerva, 2007), 58.

38 Rainbow Pride Ehime, "Lower House election of 2012," 2012, http://blogs.yahoo.co.jp/ project_gl05/63786456.html, accessed 3 May 2016; Rainbow Pride Ehime, "Lower House election of 2014," 2014, http://blogs.yahoo.co.jp/project_g105/65086604.html, accessed 3 May 2016. 
Shibuya Ward's same-sex partnership certificates, Prime Minister Shinzō Abe said, "The current constitution does not envisage marriage between people of the same sex." ${ }^{39}$ The LDP thus offers unconditional support on the social value of gender dualism, although some LDP lawmakers, such as Yōko Kawakami (justice minister), Karen Makishima, and Hiroshi Hase, have individually spoken out in favour of sexual minority issues. At the National Diet, a nonpartisan lawmakers' federation was established in January 2015 for jointly proposing a LGBT anti-discrimination bill, with members from the LDP, Kōmeitō, the Democratic Party, and others. ${ }^{40}$ Perhaps the most fundamental condition for policy change is changes in basic social values-in particular, views on and clear understandings of LGBT rights. Changes in the importance of citizen values expressed in public opinion could increase issue salience and provide a strong signal to elected policy makers in Japan's secular party system. Policy makers' actual attentiveness to what people think (or policy makers' perceived salience) then increases the likelihood of policy change.

\section{Shibuya's Adoption of LGBT Inclusive Policies}

At the national level, LGBT support groups and academics interact with sympathetic LDP lawmakers, but the sexual minority group representing only "7.6 percent" of the Japanese population is yet to receive strong support from the straight majority for electoral competition. ${ }^{41}$ The LDP has been challenged by LGBT support groups but the distribution of power is so concentrated that the interaction has been very limited. The scope of conflict over sexual minority rights is so narrow that the governing conservative coalition does not seek to reduce the policy to morality politics or a normative right or wrong at the national level. So far the LDP has tried to neutralize the minority demands, in order to maintain the existence of its conservative values. The GID law is a case in point. The legislation was only an incremental change from the existing family law to avoid a direct conflict with the minority group. The legislative intention may appear to be supportive of LGBT rights, yet as discussed above, the application of the law will end up preserving the norm of heterosexuality. This legislative manipulation is closely linked to the closed opportunity structures that are less likely to create a dynamic process of competing coalitions. Given the low degree of openness in the LGBT policy subsystem, the debate on sexual minority rights has thus become localized to seek new institutional venues and increase attention from the media and a community audience.

39 House of Councillors, Minutes of plenary session, 189th session of the Diet, 18 February 2015.

40 "LGBT chōtōha giin sabestu bōshi e rippō kentō" [LGBT nonpartisan federation of law-makers will investigate on legislative measures for anti-discrimination], Tokyo shinbun, 28 January 2015.

41 Dentsu Diversity Lab, “News release,” 23 April 2015. 


\section{The opportunity structure in central-local relations}

Japan operates under state-centric governance, in which the unitary system is institutionalized to establish a division of labour among levels of government with a state-centric gate-keeping capacity (its capacity to influence policy decisions). Local governments have primarily an implementation role to play if top-down national policy targets are to be met. However, the static notion of such governance cannot easily account for the dynamics of real-life experience in Japan. Japanese local governments often interpret the role of the opportunity structures and adapt them to meet their own locally specific needs without, normally, completely superseding the hierarchical order. The LDP's reluctance to address sexual minority rights or its indecisive stance that same-sex marriages are neither legalized nor prohibited has created the openness of political opportunities for urban governments to exploit for policy change at the local level. Indeed, in response to Shibuya's proposed ordinance for same-sex partnership, Sadakazu Tanigaki, secretary-general of the LDP, conceded the absence of a legal code for same-sex marriage by saying: "I think there would be huge repercussions in our society if a municipality began to address such a fundamental problem on its own when there is no related national law in place." ${ }^{42}$ In Shibuya, local chief executives and LGBT support groups deliberately moved the sexual minority issues into a different institutional venue: local government. They sought to meet the need of community diversity in an autonomous policy process with little interference from the national government. They successfully framed the issue of same-sex partnership by describing the painful hardships of the minority groups, such as hospitals' refusal to give visitation rights to their partners at intensive care units, rather than promoting it as a matter of abstract civil rights. ${ }^{43}$ In late April 2015, Ken Hasebe, who proposed recognition of same-sex partnership in Shibuya, became its new mayor.

\section{Agent's localized motives and actions}

Those who live in urban areas are exposed to diverse life styles and are more inclusive and appreciative of differences ${ }^{44}$ A positive relationship between educational level and tolerance for diversity has also been noted by many

\footnotetext{
42 “Tanigaki-shi, dōsei kappuru jōreian ni kenen hōritsu to no seigōsei shiteki” [Mr. Tanigaki is concerned about the proposed same-sex partnership ordinance and points out its compatibility with law], Asahi shinbun, 10 March 2015. Article 94 of Japan's constitution states: "Local public entities shall have the right to manage their property, affairs and administration and to enact their own regulations (local ordinance) within law" [italics added].

43 For local government's initiatives to take such a pragmatic stance toward a visible minority problem, see Katherine Tegtmeyer Pak, "Cities and local citizenships in Japan: overcoming nationality?" in Local Citizenship in Recent Countries of Immigration: Japan in Comparative Perspective, ed. Takeyuki Tsuda (Lanham, MD: Lexington Books, 2006), 67.

44 See, for example, David C. Nice, "State deregulation of intimate behavior," Social Science

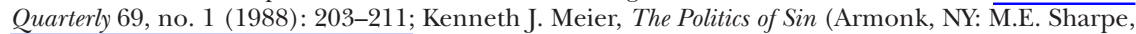
1994).
} 
researchers. ${ }^{45}$ These environmental parameters are expected to structure the political process of policy making. Functionalists tend to assume that policy making is carried out in response to such environmental factors or collective needs yet neglect the dynamic process of governance in which agents purposively steer a polity. Let us take the example of the twenty-three city wards of Tokyo, where youth migration to these wards has been shaping the diversity of communities. Minato, Chiyoda, and Shibuya wards are exceptional in their environmental factors that influence citizens' tolerance for community diversity: working-age population (as percentage of total population-the national average is 60.7 percent), income (per taxpayer income—the national average is $¥ 3.2$ million), and education (university graduates as percentage of total population-the national average is 20.9 percent). The measurement of the enabling factors indicates that these wards have ranked among the top three municipalities in Japan: 71.5 percent, $¥ 9.0$ million, 52.2 percent for Minato; 70.1 percent, ¥7.6 million, 53.4 percent for Chiyoda; and 72.5 percent, $¥ 6.8,47.2$ percent for Shibuya, respectively. ${ }^{46}$ Yet the three wards, with their similar environments, are not all equally responsive to sexual minority issues. In the case of Shibuya Ward, the human agents were able to collectively interpret the opportunity structures and fit them to the locally specific conditions of sexual minority issues. This study finds that the agent effects largely explain why Shibuya adopted the policy while others with a similar policy environment did not.

Hasebe, who used to work for an advertising agency and had business contacts with LGBT individuals, played a key role in getting the recognition of same-sex partnership on the local agenda in Shibuya. In 2003 he successfully ran as an independent candidate for the Shibuya Ward Assembly and served as a ward councillor for three consecutive terms (2003-2015). In April 2015 he won the mayoral race on a platform of creating an international city of diversity. He is a successful entrepreneur who attempted to persuade a limited segment of Shibuya's political elite and interests groups to endorse his policy ideas rather than waiting for the spontaneous formation of a community consensus. Around 2012, as ward councillor, he utilized his skillful entrepreneurial skills by framing the inclusive LGBT policies in a way that would offer a solution favouring the policy stakeholders' political leaning. Generally speaking, LGBT groups seek to present the issue of same-sex

45 See, for example, Richard Seltzer, "AIDS, homosexuality, public opinion, and changing correlates over time," Journal of Homosexuality 26, no. 1 (1993): 85-97; James L. Gibson, "Homosexuals and the Ku Klux Klan: a contextual analysis of political tolerance," Western Political Quarterly 40, no. 3 (1987): 427-448. A recent study on Japan's acceptance of homosexuality also confirms a positive relationship between education and acceptance as well as between urban living and acceptance. See Hideki Ishihara, "Nihon ni okeru dōseiai ni taisuru kanyō no kakudai" [Increasing levels of tolerance toward homosexuality in Japan], Sōkan shakaigaku 22 (2012): 23-41.

46 The figures in this section are based on Statistics Bureau, "Heisei 22-nen kokusei chōsa," [Population Census 2010], http://www.stat.go.jp/data/kokusei/2010/, accessed 12 August 2016. 
partnership as pertaining to civil rights while their opponents address it as a moral issue. Hasebe effectively facilitated greater inclusion for those Shibuya councillors who had little interest in sexual minority issues. He recalled: "In the past, we had often called for LGBT protections as a human rights issue but I decided to approach the issue in a locally-specific Shibuya way under the slogan of building cultural diversity in the international city." ${ }^{47}$ The media coverage of former Takarazuka performer Koyuki Higashi and her partner Hiroko Masuhara, who were actively advocating the proposed ordinance as a civil rights issue, and were the first recipient couple of Shibuya's same-sex partnership certificate, drew public attention to same-sex partnership. While the proposed ordinance on same-sex partnership gained a high level of media attention, the policy process of this local innovation was characterized by the involvement of a limited group of actors who had a direct interest in the issue. The morally charged same-sex partnership issue produced the less distinctive process of policy making, which lacked an overt moral dimension, than morality politics theory would anticipate.

In 2003 Hasebe established a voluntary group called "green bird," and started a campaign to "clean the town" in Harajuku/Omotesandō (part of Shibuya Ward). The anti-litter campaign spread to other parts of Japan, including Kabukichō (part of Shinjuku Ward) where LGBT Japanese comfortably express their sexuality in public. He met many sexual minority volunteers and learned first hand about the problems they face in their dayto-day lives. He closely discussed the real experiences and feelings of sexual minorities with transgender activist Fumino Sugiyama, who became a strong information provider in the agenda-setting process of Shibuya's same-sex partnership certificates. ${ }^{48}$ Over time Hasebe came to believe it was necessary for Shibuya to become a mature urban community and that its public spaces must be more inclusive and appreciative of differences. ${ }^{49}$ In June 2012, he proposed same-sex partnership certificates to symbolically recognize samesex couples and, in favour of building Shibuya's community diversity, then mayor Toshitake Kuwabara promised to explore the possibility of issuing such certificates to be congruent with national policy and law. ${ }^{50}$ While continuing to emphasize the importance of community diversity, Hasebe's proposal gained strong support within the ward assembly. Another independent assembly councillor, Mari Okada, who had studied in Massachusetts and was familiar with LGBT issues in the US, requested swift action from the mayor. ${ }^{51}$ In July 2014 Mayor Kuwabara created an Investigative

47 Shibuya Ward Assembly, Minutes of plenary session, 8 June 2012, 99-116; Ken Hasebe, interview by author, Tokyo, 22 April 2016.

48 Kira Esmralda, Dōsei pātonāshippu shōmei hajimarimashita [Japan's first same-sex partnership certificate] (Tokyo: Pot Pub Co., 2015), 10-51.

49 Ken Hasebe, interview by author, Tokyo, 22 April 2016; Shūji Minato (Secretary of Mayor's Office, Shibuya Ward), interview by author, Tokyo, 22 April 2016.

50 Shibuya Ward Assembly, Minutes of plenary session, 8 June 2012, 107-110.

51 Shibuya Ward Assembly, Minutes of plenary session, 19 June 2014, 101. 
Commission on the Enactment of Shibuya Ward's Ordinance for Promoting Respect of Community Diversity. In other words, without explicitly challenging the established central-local government relations, the mayor nevertheless attempted to exploit the opening of a policy window in the absence of a legal code for same-sex marriage.$^{52}$ Local government thus occupies a strategic position to implement a cohesive policy that would meet specific local needs, due to a lack of support from national government.

The commission was initially comprised of eight representatives: academics, lawyers, and Shibuya Ward's employees. LGBT people were invited to share their experiences with the commission members, which presented a key opportunity for vigorous discussion. One of the members, a former superintendent of education, admitted that never in her entire professional career had she been aware of the existence of LGBT children. ${ }^{53}$ The experiences of LGBT people served as an impetus that assisted the commission in embarking toward a process of serious inquiry, with eyeopening results. In January 2015 the commission submitted to the mayor a report that suggested the issuance of certificates for same-sex couples as well as protective measures for other community diversity issues. It also emphasized the importance of commitment to same-sex partnership by including two application requirements: a notarized deed to declare that each would act as a guardian for their partner and a notarized document promising they will live together. ${ }^{54}$ To pass an ordinance, the main thrust by pro-same-sex partnership councillors in the ward assembly was to promote the sexual minority issue as an opportunity to create Shibuya's cutting image at home and abroad rather than for the sake of civil rights per se. Hasebe pushed the issue by saying, "We need to be on par with London, New York and San Francisco as a cultural center." ${ }^{55}$ As same-sex partnership was a potentially divisive issue the mayor had to grapple with in the ward assembly, he decided to address it as a matter of building cultural diversity in the international city. He successfully promoted it as a matter of community development rather than that of a divisive redistribution of societal and religious values involved in sexual minority issues. The relatively low salience of same-sex partnership in the agenda-setting process provided him with the opening of a policy window to move the item of same-sex partnership onto formal municipal agendas.

52 For the argument on such available political space, see Katherine Tegtmeyer Pak, "Foreigners are local citizens, too: local governments respond to international migration in Japan," in Japan and Global Migration: Foreign Workers and the Advent of a Multicultural Society, eds. M. Douglass and G.S. Roberts (London: Routledge, 2000), 245.

53 Ken Hasebe, interview by author, Tokyo, 22 April 2016; Esmralda, Dōsei pātonāshippu shōmei hajimarimas, 43-46.

54 Shibuya Ward Assembly, Minutes of plenary session, 3 March 2015, 111-114.

55 "Gay rights movement gains steam in Japan," Wall Street Journal, 3 June 2015. Some researchers would say that he felt "international pressure" to take such a municipal initiative. See, for example, Jacob Ausderan, "How naming and shaming affects human rights perceptions in the shamed country," Journal of Peace Research 51, no. 1 (2014): 81-95. 
In February 2015 the news of Shibuya's decision to propose an ordinance on "partnership certificates" received national media attention. ${ }^{56}$ On March 31, 2015, the ward assembly passed by majority vote the Ordinance for Promoting Respect of Gender Equality and Diversity in the ward. Article 4 of the ordinance specifically refers to respect for the "human rights" of sexual minorities and Article 10 introduces the issuance of "partnership certificates" by the ward. In 2003 Kuwabara was first elected as mayor of Shibuya Ward with a strong endorsement from the national LDP, yet as he served three four-year terms, he became less responsive to LDP's conservative leadership. Indeed, when the ward assembly was about to pass the ordinance, the Tokyo chapter of the LDP stated, "If by any chance the ordinance is passed, our next mayor will repeal it." ${ }^{57}$ All 7 LDP councillors and 3 independents out of 31 votes opposed it. ${ }^{58}$ The national headquarters of the LDP did not allow free votes for those LDP members, although only two LDP councillors unconditionally opposed the official recognition of same-sex partnership..$^{59}$ Some commentators individually warned of the danger of a "collapse of family values," ${ }^{\prime 6}$ yet as pro-same-sex partnership forces did not always seek to portray their objectives as purely civil rights issues, anti-samesex partnership forces did not overtly bring a normative right or wrong dimension either. The assembly debate largely focused on partner benefits, which were less morally controversial than partnership registration itself. ${ }^{61}$ The key conservative councillors, such as LDP councillor Mari Sato, did not have a genuine interest in politicizing the policy agenda as a morality issue as it appeared that the Shibuya residents accepted it as an issue of community diversity. ${ }^{6}$

The deliberation at the ward assembly clearly indicates that the intention of the ordinance was not to merely offer a legal framework through same-sex partnership, but rather to promote the social recognition of same-sex partnership developed from the interaction of individuals in the community. ${ }^{63}$ The social recognition, which would help shape the values of citizens in the community, was expected to offer practical solutions to the problems that same-sex couples face in their day-to-day lives, such as co-signing of tenancy agreements for rental housing, hospital visitation and medical decisionmaking rights for their partners, and family-related employment benefits. ${ }^{64}$ Although not legally binding, the ordinance prohibits businesses, hospitals,

\footnotetext{
2015.

See for example, "Shibuya Ward plans vote on same-sex marriage," Japan Times, 12 February

Shūji Minato, interview by author, Tokyo, 22 April 2016.

Shibuya Ward Assembly, Minutes of plenary session, 31 March 2015, 186-196.

Ken Hasebe, interview by author, Tokyo, 22 April 2016.

Esmralda, Dōsei pātonāshippu shōmei hajimarimas, 57.

See for example, Shibuya Ward Assembly, Minutes of plenary session, 5 June 2015, 99-106.

Shibuya Ward Assembly, Minutes of plenary session, 31 March 2015, 187-188.

Shibuya Ward Assembly, Minutes of plenary session, 2 March 2015, 60-72.

64 Ken Hasebe, interview by author, Tokyo, 22 April 2016; Esmralda, Dōsei pātonāshippu shōmei hajimarimas, 54.
} 
real estate firms, and residents in Shibuya from discriminating against sexual minorities. The mayor can also "guide" and "recommend" those organizations and individuals, if considered necessary, to treat holders of the certificates in the same way as married couples (Article 15-2,3). He can even threaten to name and shame violators (Article 15-4). The jurisdiction granted to the mayor could function as a de facto legal binding instrument and deter discrimination.

Following the passage of the ordinance, the outgoing mayor of Shibuya endorsed Hasebe to be his successor as new mayor, and Hasebe succeeded in winning the vote. This election was a closely watched three-way competition between the LDP-backed candidate, opposition-backed candidate, and Hasebe, without official support from any political parties. The LDP-backed candidate polled 29.1 percent, the opposition-backed candidate polled 31.2 percent, and the independent candidate polled 36.4 percent. ${ }^{65}$ According to Japan Broadcasting Corporation's exit polls, Hasebe gained the most unaffiliated votes. He was adept at using his same-sex partnership initiative, together with the incumbent mayor's endorsement, to effectively attract publicity. Nonetheless, he strategically did not run on a single issue (sexual minority issue), but through a platform of broad policies for the majority, as the two other candidates did. ${ }^{66}$

\section{Policy diffusion as a determinant}

In 1989 Denmark became the first country to establish a national system of "registered partnerships" for both homosexual and heterosexual couples and it was quickly followed by other Scandinavian countries. The Investigative Commission on the Enactment of Shibuya Ward's Ordinance for Promoting Respect of Community Diversity acted as a transfer agent, shuttling knowledge about registered partnerships and the Nordic model, which was then introduced to the office of Shibuya's mayor. ${ }^{67}$ The mayor and pro-same-sex partnership ward councillors accepted the fundamental ideas of registered same-sex partnerships, but the transferred policy instruments had to be adapted to the urban scale and the locally specific needs. There was little practical experience to be gained from other municipalities in Japan, since at that time, no Japanese local governments had created such a system under the enactment of local ordinances. The mayor innovatively uncovered the

65 Shibuya Ward, "Mayor April 26, 2015 execution Shibuya election vote breaking news, [sic]" 2015, http://www.city.shibuya.tokyo.jp.e.mu.hp.transer.com/eac/voting/20150426tou_k.html, accessed_15 August 2016.

66 Ken Hasebe, interview by author, Tokyo, 22 April 2016; Esmralda, Dōsei pātonāshippu shōmei hajimarimas, 54-55.

67 Shibuya Ward Assembly, Minutes of plenary session, 2 March 2015, 7. For arguments on local governments as transfer agents for policy learning from abroad, see Harold Wolman and Ed Page, "Policy transfer among local governments: an information-theory approach," Governance 15, no. 4 (2002): 477-501; Michele M. Betsill and Harriet Bulkeley, "Transnational networks and global environmental governance,” International Studies Quarterly 48, no. 2 (2004): 471-493. 
little-known issue of sexual minorities by linking it to the topic of the international city's cultural diversity. The lawyers and academics who worked with the commission dealt with the practical effects on the day-to-day protection of sexual minorities, so that they would not come into conflict with the Family Registration Law yet get closer to the actual benefits of a legal registration of marriage.$^{68}$ In supporting Shibuya's urban community building as a whole, the commission did not want it to appear as if they were narrowly focused on the issue of a "partnership ordinance," but rather successfully proposed an ordinance of the multiple dimensions of community diversity, according to which Shibuya residents, individually and collectively, would not discriminate against minorities, whether they are women, LGBT people, people with disabilities, or foreigners ${ }^{69}$

Immediately after Shibuya's announcement about the proposed ordinance, Setagaya Ward councillor Kamikawa posted on Twitter, saying, "We follow suit." ${ }^{70}$ Since there was a slim chance to pass such an ordinance at the conservative-dominated Setagaya Assembly, Setagaya Mayor Nobuto Hosaka used his discretionary power to issue the yōko gyōsei (administrative guidelines) for addressing the issue of same-sex couples in Setagaya Ward. On November 5, 2015, neighbouring Setagaya Ward started issuing partnership certificates to same-sex couples. Geographical proximity is likely to encourage the diffusion of policy ideas, but policy entrepreneurs must exploit the proximity for policy innovations. ${ }^{71}$ They tend to adopt a policy innovation when they interact with their neighbours who share an interest in a specific policy area. ${ }^{72}$ In May 2014 Kamikawa was invited by the mayor of Takarazuka City, Tomoko Nakagawa, in the Kansai region, to a training session for its employees to talk about the necessity of LGBT policy. On June 1, 2016, Takarazuka, home of the cross-dressing all-female theatre troupe Takarazuka Revue, also began issuing official partnership certificates for same-sex couples. A history of progressive local affairs certainly supported the crafting of the local policy. ${ }^{73}$ Mayor Nakagawa was cited as saying, "We hope as many people as possible use it [same-sex partnership certificates]," while drawing on Setagaya's experience of yōko gyōsei. ${ }^{74}$ Policy innovation

68 Esmralda, Dōsei pātonāshippu shōmei hajimarimas, 50-51.

69 Esmralda, Dōsei pātonāshippu shōmei hajimarimas, 56-58.

70 Esmralda, Dōsei pātonāshippu shōmei hajimarimas, 84.

71 Jack L. Walker, "The diffusion of innovations among American states," American Political Science Review 63 (1969): 880-899; Francis S. Berry and William D. Berry, "Innovation and diffusion models in policy research," in Theories of the Policy Process, ed. P.A. Sabatier (Boulder, CO: Westview Press, 1999), 172-178.

72 Michael Mintrom and Sandra Vergari, "Policy networks and innovation diffusion: the case of state education reforms," The Journal of Politics 60, no. 1 (1998): 126-148.

73 Tegtmeyer Pak, "Cities and local citizenships in Japan," 67. For the history of the all-female Takarazuka Revue, see Jennifer Robertson, Takarazuka: Sexual Politics and Popular Culture in Modern Japan (Berkeley: University of California Press, 1998).

74 "Takazuka-shi ga dōsei kappuru ni’ntei e" [City of Takarazuka will recognize same-sex couples], Kobe shinbun, 30 November 2015. 
front-runner Setagaya served as a point of reference for Mayor Nakagawa. Iga City in Mie and Naha City in Okinawa followed in Setagaya's footsteps by starting to issue partnership certificates under the guidelines of yōko gyōsei on April 1, 2016 and on July 8, 2016, respectively. Therefore, it appears that policy transfer will be a key determinant of LGBT policy adoption at the local level.

The theories of moral politics have been developed in a study area that seeks to examine an essentially domestic process of policy making. But policy adoption or policy change at the domestic level can take place in an international context where transnational actors and networks exert much of their influence on country policy. Since the Japanese national government remains indifferent to the demands of sexual minorities, LGBT communities have sought a transnational network for policy advocacy. In 1984 the Japanese branch of the International Gay Association (IGA) was established in Tokyo to promote civil rights in LGBT communities. ${ }^{75}$ In 1986 the first IGA Asian Conference was held in Tokyo. In 1994 the International Lesbian, Gay, Bisexual, Trans and Intersex Association (ILGA, formerly IGA) began to organize Japan's first gay pride parade, the Tokyo Pride Parade. In 2012 when Shibuya Ward became interested in the issue of same-sex partnership, the local opportunity structure transformed into a significantly more open political environment for civil rights activism. Both their transnational linkages and the political openness allowed the LGBT groups to share the globally emerging norms of sexual minorities' rights and foreign-originated policy ideas with Shibuya's policy-making stakeholders. In other words, the role of policy diffusion played by non-governmental actors in transnational networks can be seen as a complement to the government-centric hard transfer. ${ }^{76}$

Without interest groups that are able to expand the scope of the conflict to electoral politics, there would be little need for the dominant governing coalition to reconsider its policy belief. However, the conservative politicians' willingness to accept that homosexuality is not a mental disorder did not derive from changes to their core beliefs, but rather from international pressure to which they needed to quickly adjust. In 1990 the General Assembly of the World Health Organization (WHO) removed homosexuality from their list of mental disorders, since the panel of specialists came to recognize such a diagnostic reference as scientifically baseless. The ILGA was at the forefront of the campaign to hold the WHO accountable for considering

In 1986, the International Gay Association (IGA) was renamed the International Lesbian, Gay, Bisexual, Trans and Intersex Association (ILGA), which is the world federation of LGBT organizations dedicated to achieving equal rights for lesbian, gay, bisexual, transgendered, and intersex people.

76 Diane Stone, "Transfer agents and global networks in the 'transnationalization' of policy," Journal of European Public Policy 11, no. 3 (2004): 545-566; Diane Stone, "Transfer and translation of policy," Policy Studies 33, no. 6 (2012): 483-499. 
homosexuality to be a disease. In 1994 Japan's Ministry of Health and Welfare followed the WHO's decision by removing homosexuality from the mental disorder treatment list and in the same year the Ministry of Education also removed homosexuality from the categories of sexual misconduct listed in its administrative guidance. ${ }^{77}$ International organizations are authoritative venues of knowledge production, a role which provides them with substantial leverage to proselytize member states to initiate policy reform.

\section{Conclusion}

Shibuya's stand-alone initiative was largely the result of decisions made by specific policy entrepreneurs who were able to invoke a combination of effective strategies, especially through the wise use of issue framing, while recognizing and acting upon structural opportunities for policy solutions. The case of Shibuya's LGBT policy suggested two primary types of opportunity openings: a discretionary political opportunity which local authorities can exploit in the absence of national regulations, and an issue-specific opportunity upon which local authorities can act in the absence of a religious versus secular conflict in the party system. The entrepreneurs took advantage of this issue-specific opportunity to undertake pragmatic policy solutions rather than redistributing citizen values. Local authorities, with similar policy environments, were not all equally responsive to the issue of sexual minorities. Without Hasebe's initiative as ward councillor and mayor, and former mayor Kuwabara's commitment, the progressive proposal may never have got onto a policy agenda. There were also no locally active gay/lesbian organizations that could directly participate in the policy process that would conform to lobbying politics or interest group politics, although key policy makers had personal contact with LGBT individuals. The structure of decision making around the policy issue of same-sex partnership was shaped by a limited group of actors, i.e., the mayors, the Investigative Commission, and supportive ward councillors, who were heavily involved in the issue. The political conflict was fought with a limited scope where mayoral leadership minimized politicization of the decision-making processes. The policy image of same-sex partnership was framed from a perspective of community diversity, rather than that of divisive societal values or religious values so that the political conflict would not be expanded beyond the existing group of actors in the ward assembly. The mayor's office successfully avoided reducing the issue of same-sex partnership to the legal sanction of what is normatively right or wrong. Otherwise, as morality politics theory predicts that moral disputes will reflect the influence of party and electoral competition, the case of

77 "Dōseiai sabetsu no kijutsu seito shidōsho kara sakujo" [Remove the discriminatory description of homosexuality from the student counselling manual], Nihon keizai shinbun, 25 November 1994. 
Shibuya's LGBT policy adoption could have been more politicized and become a socially divisive issue. As the issue of same-sex partnership hardly engaged the fundamental values of Shibuya's voters, the opponents of LGBT rights were unable to effectively frame Shibuya's same-sex partnership certificates as morality issues for voter mobilization. The core belief in sexual minorities' rights prevailed in the policy agenda setting yet required the political manipulation of the policy process. The political process of Shibuya's LGBT policy adoption had not evolved around the redistribution of societal values, but rather relied on utility considerations, such as material benefits and practical solutions for the day-to-day problems of sexual minorities. To prevent the politicization of the proposal, the mayor's office needed to frame policy concerns that would promote Shibuya's vitality, raising the salience of economic considerations as well as the international reputation for Shibuya. The policy processes of Shibuya's same-sex partnership fit neither morality politics nor interest group politics (within the category of pluralist influence), but rather resemble the politics of polyarchy, in which policy may be adopted by a set of limited agents for material interest representation, but then policy adoption cannot take place except within the process of the majority voters' approval.

Curtin University, Perth, Australia, October 2016 